\title{
Stereoselective preparation of quaternary 2-vinyl sphingosines and ceramides and their effect on basal sphingolipid metabolism
}

Raquel Calderón, ${ }^{\text {d,e }}$ Nerea Mercadal, ${ }^{a}$ José Luis Abad, ${ }^{\mathrm{d}}$ Xavier Ariza, ${ }^{\mathrm{a}, \mathrm{b}, \mathrm{c}}$ Antonio Delgado, ${ }^{\mathrm{d}, \mathrm{e}}$ Jordi Garcia, ${ }^{* a, b, c}$ Aleix Rodríguez ${ }^{\mathrm{a}, \mathrm{b}}$ and Gemma Fabriàs ${ }^{* \mathrm{~d}}$

${ }^{a}$ Departament de Química Inorgànica i Orgànica, Secció de Química Orgànica, Facultat de Química, Universitat de Barcelona (UB), Martí i Franquès 1, 08028-Barcelona, Spain. Email: jordigarciagomez@ub.edu

${ }^{b}$ Institut de Biomedicina de la Universitat de Barcelona (IBUB), Barcelona, Spain

${ }^{c}$ CIBER Fisiopatología de la Obesidad y la Nutrición (CIBERobn), Instituto de Salud Carlos III, Madrid, Spain

${ }^{d}$ Consejo Superior de Investigaciones Científicas (CSIC), Institut de Química Avançada de Catalunya (IQAC-CSIC), Research Unit on Bioactive Molecules (RUBAM), Calle Jordi Girona 18-26,08034-Barcelona, Spain.E-mail: gemma.fabrias@iqac.csic.es ${ }^{\mathrm{e}}$ Departament de Farmacologia, Toxicologia i Química Terapèutica, Unitat de Química Farmacéutica (Unitat Associada al CSIC), Facultat de Farmacia, Universitat de Barcelona (UB), Avda. Joan XXIII s/n, 08028-Barcelona, Spain 
GRAPHICAL ABSTRACT:

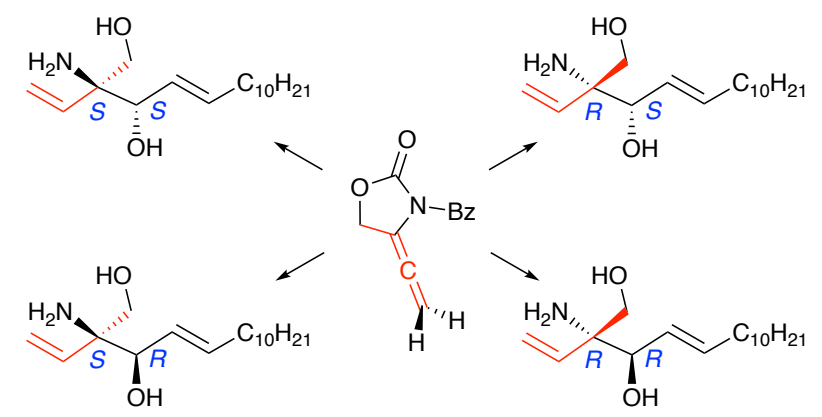

ABSTRACT: The dicyclohexylborane-mediated addition of allene $\mathbf{1}$ to (E)-2-tridecenal affords a quaternary protected 2-amino-2-vinyl-1,3-diol in good yield as a single diastereomer. This compound is readily transformed into the four stereoisomers of the quaternary (E)-2-vinyl analogs of sphingosine. The metabolic fate and the effect of these compounds on the basal sphingolipid metabolism in human A549 lung adenocarcinoma cells has been studied, together with the ceramide analog of the most relevant vinylsphingosine derivative. 


\section{Introduction}

Sphingolipids are a family of natural products that play essential roles as structural cell membrane components and also in cell signaling through a complex metabolic network involving specific enzymes. From a structural point of view, most mammalian sphingolipids share a common 2-amine-1,3-diol moiety arising from (E)-2-amino-4-octadecen-1,3-diol (sphingosine). Interestingly, some structural analogs of sphingosine and/or ceramides ( $N$-acyl sphingosines) can act as selective inhibitors of sphingolipid metabolism enzymes and they exhibit interesting pharmacological properties. ${ }^{1-3}$ In particular, Boumendjel and Miller reported that compound 2 (Figure 1, mixture of isomers), a quaternary vinyl analog of dihydrosphingosine 1-phosphate, exhibits potent inhibition of sphingosine 1-phosphate lyase. ${ }^{4}$

Based on the above precedents, it is conceivable that the introduction of the 2-amino-2-vinyl1,3-diol core as part of the sphingolipid framework represents an attractive modification for the design of new modulators of sphingolipid metabolism. In this work, we present an adaptation of our previously reported protocol ${ }^{5}$ to the enantioselective synthesis of quaternary 2-vinyl sphingosines 9 (Figure 1). In addition, studies on their cellular metabolism, cellular toxicity and effects on basal sphingolipid metabolism in human A549 lung adenocarcinoma cells are discussed. 


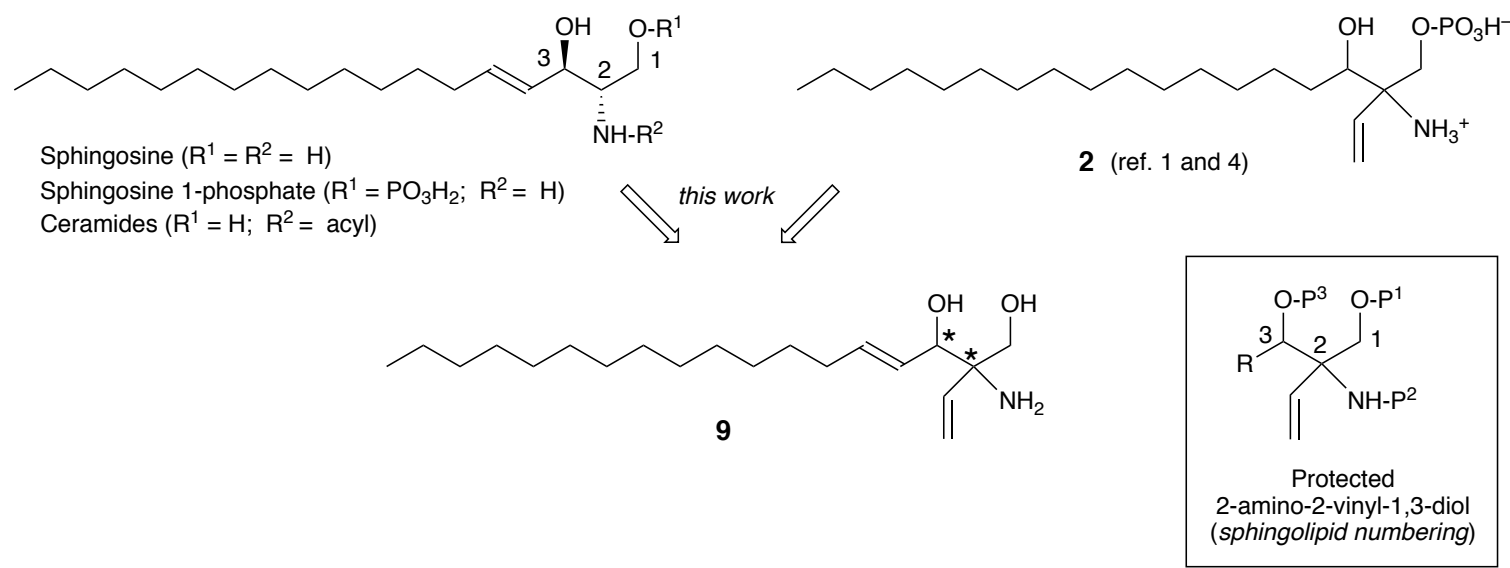

Fig. 1 Sphingolipids, 2-vinyl dihydrosphingosine 1-phosphate (2), and 2-vinylsphingosines (9)

\section{Results and discussion}

\section{Chemistry}

We recently reported a highly stereoselective addition of $N$-tosyl allene $\mathbf{3}$ to aldehydes leading to protected tosylcarbamates $( \pm)-4 .{ }^{5}$ This one-pot process is based on the hydroboration of the allene with $\left(c-\mathrm{C}_{6} \mathrm{H}_{11}\right)_{2} \mathrm{BH}$ at the less hindered face of the terminal double bond to generate an allylborane which could be added in situ to an aldehyde (Scheme 1). However, in practice, the use of tosyl as $\mathrm{N}$-protecting group suffers from some drawbacks. First, the robust tosyl group may be difficult to remove in the final steps of a multi-step synthetic sequence. Secondly, the $N$-tosyl group favors an facile acid or base-catalyzed partial isomerization to the corresponding inner $\mathrm{N}$-tosylcarbamates 5 during work-up and/or chromatographic purification of compounds $\mathbf{4}$, leading to mixtures that are difficult to separate. 


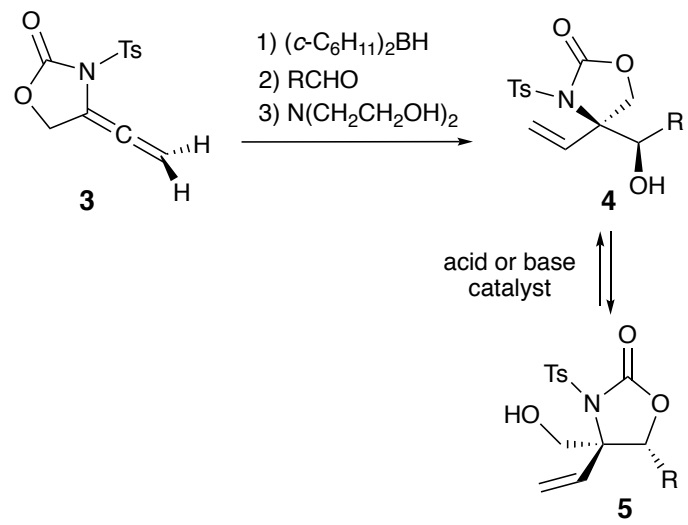

Scheme 1 Preparation of $N$-tosylcarbamates $( \pm)-4$ and their isomerization to $( \pm)-5$

These disadvantages can be avoided almost completely by using allene 1 (Scheme 2), obtained from but-2-yn-1,4-diol in $61 \%$ yield, ${ }^{6}$ in which the more easily removable $N$-benzoyl group is used as protecting group. ${ }^{7}$ We envisaged that the addition of allene $\mathbf{1}$ to $(E)$-2tridecenal would provide access to 2-vinyl sphingoid analogs 9 (Figure 1), structurally related to sphingosine. Considering the incorporation of the vinyl unit in 9, the use of $(E)-2$ tridecenal would afford a C17 long chain base, which is expected to be endowed with appropriate properties for cell permeabilization. As expected, hydroboration of 1 with (c$\left.\mathrm{C}_{6} \mathrm{H}_{11}\right)_{2} \mathrm{BH}$, in $\mathrm{CH}_{2} \mathrm{Cl}_{2}$ at $0{ }^{\circ} \mathrm{C}$ followed by addition of $(E)$-2-tridecenal, afforded carbamate $( \pm)$-6 in very high diastereochemical purity $\left(>95: 5\right.$ by ${ }^{1} \mathrm{H}$ NMR) after a hydrolytic work-up with triethanolamine and column chromatography. It should be remarked that complete migration of the benzoyl protecting group from the nitrogen atom to the newly formed secondary alcohol was observed, in this way avoiding the isomerization of 6 to the inner carbamate ( \pm -7' (Scheme 2), as was observed in the isomerization of 4 into 5 (Scheme 1). Thus, compound ( \pm )-6 was obtained in an acceptable $75 \%$ yield, after chromatographic purification, as a single diastereomer (as racemic mixture of both enantiomers). 


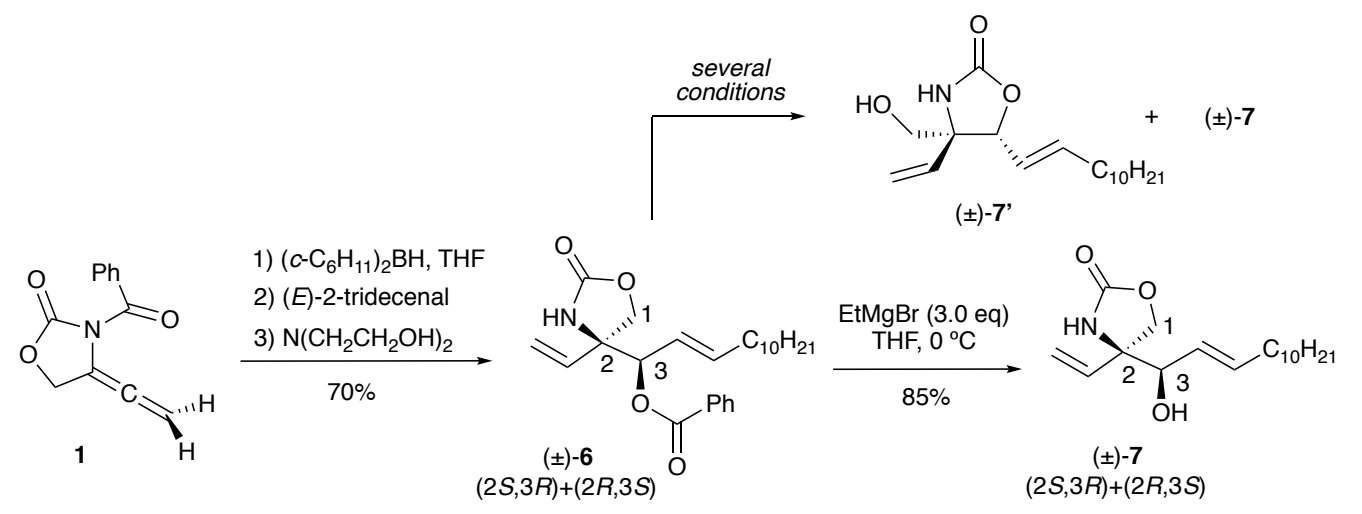

Scheme 2 Synthesis of sphingoid precursor $( \pm)-7$ from allene $\mathbf{1}$ and attempts of selective hydrolysis of benzoate $( \pm)-6$

Hydrolysis of the benzoate group in ( \pm )-6 to the desired alcohol $( \pm)-7$ avoiding isomerization to the inner carbamate was not a trivial task. A number of hydrolytic treatments with different basic $\left(\mathrm{K}_{2} \mathrm{CO}_{3}, \mathrm{LiOH}\right)$ or acidic $\left(\mathrm{H}_{2} \mathrm{SO}_{4}, \mathrm{HCl}\right)$ aqueous or methanolic media, as well as reductive treatment of $( \pm)-6$ with $\mathrm{LiBH}_{4}$ in THF, were performed leading to mixtures of both carbamates arising from the primary or the secondary alcohol $\left(( \pm)-7\right.$ and $\left.( \pm)-7^{\prime}\right)$. Gratifyingly, the use of EtMgBr in THF at $0{ }^{\circ} \mathrm{C}$ afforded the required alcohol $( \pm)-7$ in good yield with negligible isomerization. Since we were interested in the influence of the different stereoisomers of 2-vinyl sphingosines in sphingolipid metabolism, we undertook the resolution of $( \pm)-7$. This was accomplished by transformation of $( \pm)-7$ into a mixture of the corresponding diastereomeric esters 8 derived from $(R)$-methoxyphenylacetic acid $[(R)$ MPA $]^{8}$ using EDC as coupling reagent in the presence of a catalytic amount of DMAP. Esters $\mathbf{8}$ were then easily isolated by column chromatography and their configuration at C3 was inferred from $\Delta \delta$ between selected pair of protons, following the empirical method of Riguera et $a l,{ }^{9}$ as indicated in Table 1 . Since the relative configuration between C2 and C3 had already been established based on mechanistic grounds, ${ }^{5}$ the absolute configuration at both stereogenic centers in esters $\mathbf{8}$ was thus assigned. 


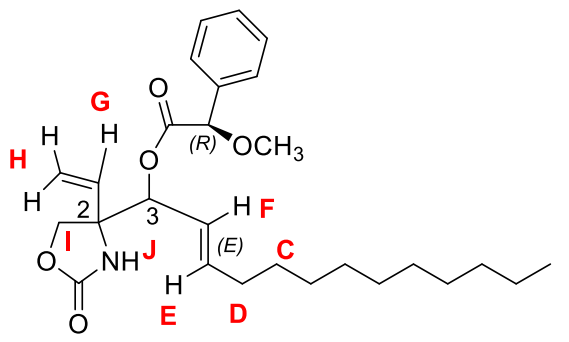

\begin{tabular}{|c|c|c|c|c|c|c|c|c|}
\hline \multicolumn{6}{|c|}{$3 S$ configuration assigned from $\Delta \delta[(2 R, 3 S)$ or $(2 S, 3 R)](R)-$ MPA esters } \\
\hline & $\delta \mathrm{H}_{\mathrm{C}}\left(^{*}\right)$ & $\delta \mathrm{H}_{\mathrm{D}}(*)$ & $\delta \mathrm{H}_{\mathrm{E}}$ & $\delta \mathrm{H}_{\mathrm{F}}$ & $\delta \mathrm{H}_{\mathrm{G}}(*)$ & $\delta \mathrm{H}_{\mathrm{H}}$ & $\delta \mathrm{H}_{\mathrm{I}}(*)$ & $\delta \mathrm{H}_{\mathrm{J}}$ \\
\hline $2 R 3 S$ & 1.16 & 1.88 & 5.59 & 5.18 & 5.83 & 5.28 & 4.11 & 5.90 \\
\hline $2 S 3 R$ & 1.29 & 2.02 & 5.91 & 5.30 & 5.62 & 5.06 & 3.85 & 5.72 \\
\hline$\Delta \delta^{S R}$ & -0.13 & -0.14 & -0.32 & -0.12 & +0.21 & +0.22 & +0.26 & +0.18 \\
\hline
\end{tabular}

$\mathbf{3} \boldsymbol{R}$ configuration assigned from $\Delta \delta[(2 R, 3 R)$ or $(2 S, 3 S)](R)$-MPA esters

\begin{tabular}{|c|c|c|c|c|c|c|c|c|}
\hline & $\delta \mathrm{H}_{\mathrm{C}}(*)$ & $\delta \mathrm{H}_{\mathrm{D}}(*)$ & $\delta \mathrm{H}_{\mathrm{E}}$ & $\delta \mathrm{H}_{\mathrm{F}}$ & $\delta \mathrm{H}_{\mathrm{G}}(*)$ & $\delta \mathrm{H}_{\mathrm{H}}$ & $\delta \mathrm{H}_{\mathrm{I}}(*)$ & $\delta \mathrm{H}_{\mathrm{J}}$ \\
\hline $2 R 3 R$ & 1.32 & 2.01 & 5.82 & 5.29 & 5.62 & 5.16 & 3.90 & 5.42 \\
\hline $2 S 3 S$ & 1.01 & 1.80 & 5.24 & 5.09 & 5.81 & 5.34 & 4.17 & 5.78 \\
\hline$\Delta \delta^{R S}$ & +0.31 & +0.21 & +0.58 & +0.20 & -0.19 & -0.18 & -0.27 & -0.36 \\
\hline
\end{tabular}

(*) $\delta$ from the center of the system

Table 1: Configurational assignment at $\mathrm{C} 3$ position of $(R)$-MPA esters 8

Enantiopure $(2 S, 3 R)-\mathbf{8}$ and $(2 R, 3 S)-\mathbf{8}$ we independently treated in basic aqueous-alcoholic media to obtain free aminodiols $(2 S, 3 R)-\mathbf{9}$ and $(2 R, 3 S)-\mathbf{9}$, respectively, in good yields (Scheme 3). 


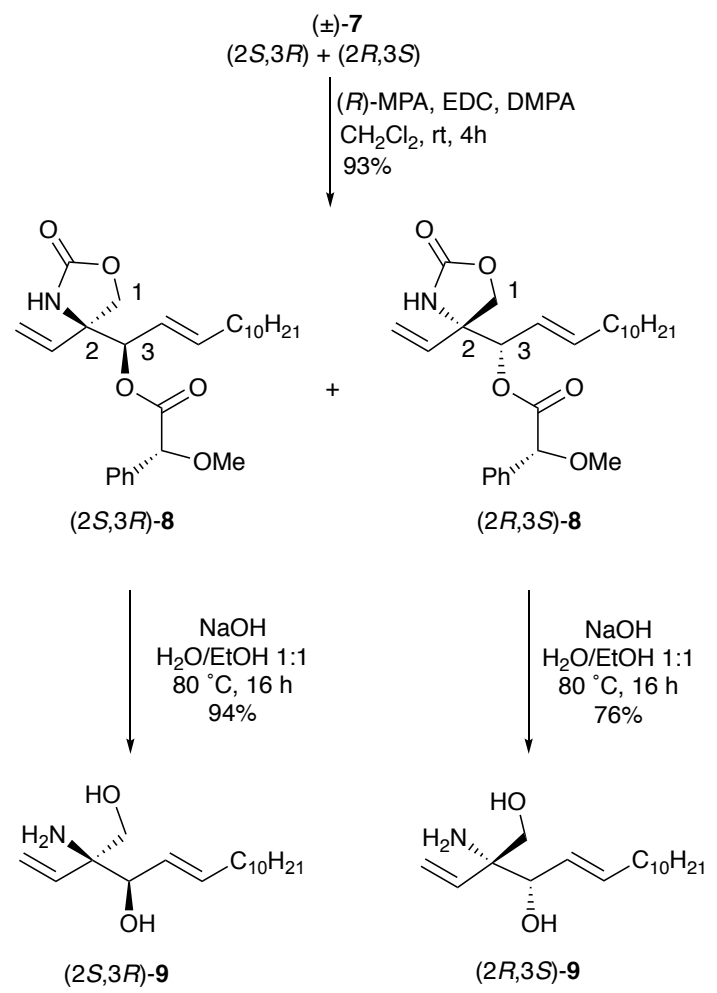

Scheme 3 Resolution of ( $( \pm)-7$ and conversion of enantiopure esters 8 into $(2 S, 3 R)-9$ and $(2 R, 3 S)-\mathbf{9}$

Regarding the preparation of the enantiomeric series, $(2 S, 3 S)$ and $(2 R, 3 R)$, we first attempted a direct inversion of the secondary alcohol in ( \pm )-7 by Mitsunobu reaction, using benzoate as nucleophile, without success. We then turned our attention to a redox two-step process based on the oxidation of $( \pm)-\mathbf{7}$ to ketone $( \pm)-\mathbf{1 1}$, followed by reduction. In practice, the Dess-Martin oxidation of $( \pm)-\mathbf{7}$ gave ketone $( \pm)$-11, which was used without further purification. The reduction of $( \pm)$-11 under Luche conditions $\left(\mathrm{Ce}(\mathrm{III}) / \mathrm{NaBH}_{4}\right)^{10}$ turned out to be only minimally stereoselective, since a roughly $1: 1$ mixture of the corresponding diastereomeric alcohols in a satisfactory 63\% yield (over two steps) was obtained (Scheme 4). Unfortunately, we were not able to efficiently isolate both diastereomeric racemates by column chromatography. Thus, we attempted the resolution of the mixture of alcohols through the formation of the corresponding diastereomeric esters 8 derived from $(R)$-MPA (Scheme 4). To our satisfaction, the four stereoisomeric esters exhibited sufficient separation by TLC. 
After column chromatographic isolation of $(2 R, 3 R)-\mathbf{8}$ and $(2 S, 3 S)-\mathbf{8}$, the amino diols $(2 R, 3 R)$ 9 and $(2 S, 3 S)-9$ were obtained in $85 \%$ and $65 \%$ yield, respectively, by basic hydrolysis. Again, the configuration at $\mathrm{C} 3$ of the diasteromeric esters $(2 R, 3 R)-\mathbf{8}$ and $(2 S, 3 S)-\mathbf{8}$ was inferred by the method of Riguera et al, based on the $\Delta \delta$ values indicated in Table 1 .

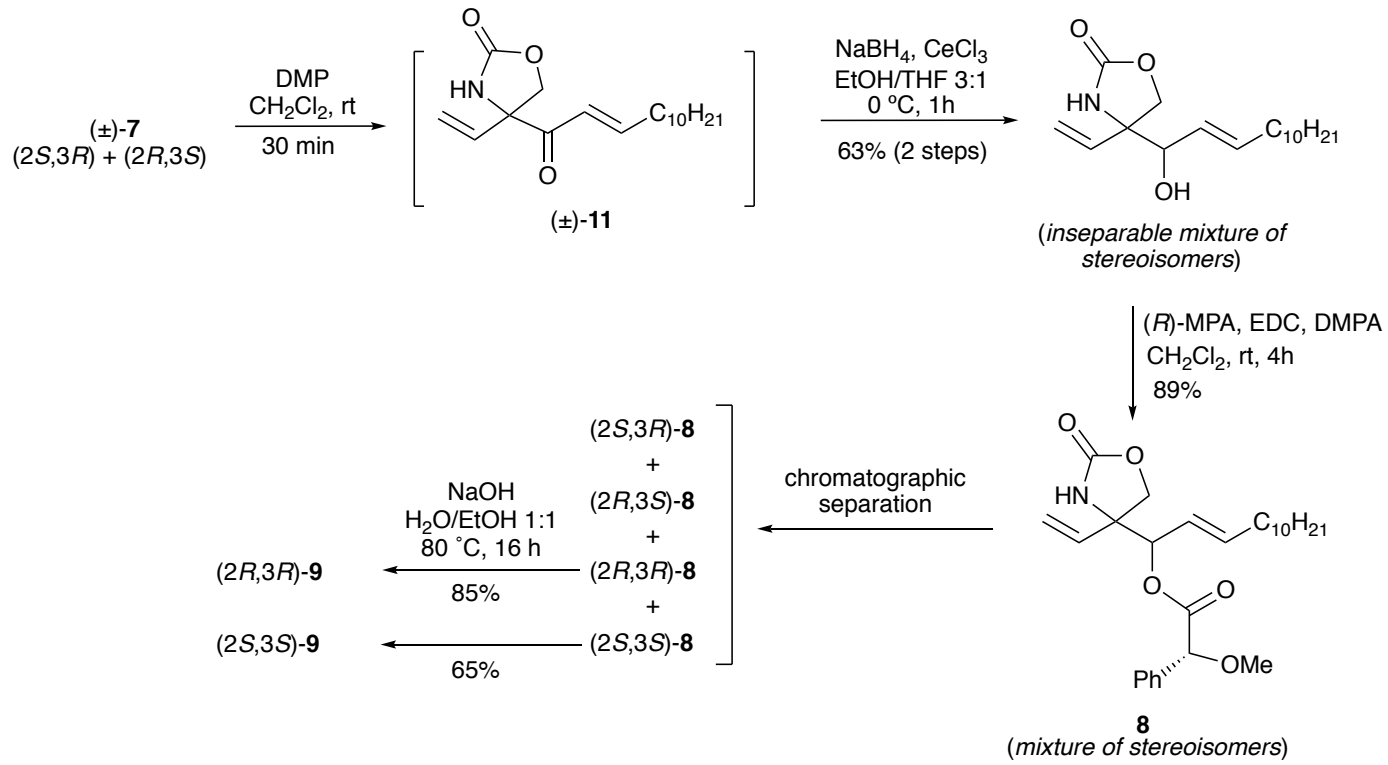

Scheme 4 Resolution of $( \pm)-\mathbf{1 1}$ and preparation of $(2 S, 3 S)$ and $(2 R, 3 R) \mathbf{8}$ and $\mathbf{9}$.

\section{Metabolism of amino diols 9.}

Treatment of A549 cells with sub-toxic concentrations (Fig. S1) of amino diols 9 revealed that only the $2 S, 3 R$ stereomer was $N$-acylated (Fig. 2A,B). Interestingly, only the C22, C24 and C24:1 acyl derivatives were formed (Fig. 2A). Since A549 cells also produce ceramides with other $N$-acyl chains, with $\mathrm{C} 16$ being also abundant ${ }^{11,12}$ (See Figure 3 ), this result suggests that $(2 S, 3 R)-9$ is a substrate of ceramide synthase 2 (CerS2), which produces long chain ceramides, but it is not a good substrate of CerS5 and CerS6, which catalyze the formation of $\mathrm{C} 16$ ceramide. ${ }^{13}$ This is the first example of a sphingoid base selectively used by a specific CerS. On the other hand, only $(2 S, 3 R)-9$ and, to a significantly lower extent, $(2 S, 3 S)-9$ are phosphorylated at $\mathrm{C} 1 \mathrm{OH}$ (Figure 2B), which supports the idea that, despite the 
presence of the vinyl group, sphingosine kinase activity takes place preferentially on the $2 S$ stereoisomer. Importantly, the above long chain $N$-acyl derivatives of $(2 S, 3 R)-9$ were metabolically stable, as neither the sphingomyelin analogs nor the glucosylceramide analogs were detected in the extracts.

To investigate the metabolic stability of amides of $(2 S, 3 R)-9$ against ceramidases, $N$ octanoylamide 10, obtained by acylation of $(2 S, 3 R)-\mathbf{9}$ with octanoic acid (EDC/DMAP), was incubated with A549 cells at sub-toxic concentrations (Figure S1). As shown in Figure 2C, the free base $(2 S, 3 R)-9$ was detected in the extracts. Furthermore, the C22, C24 and C24:1 acyl derivatives of $(2 S, 3 R)-\mathbf{9}$ were also formed (Figure 2D), indicating that amide $\mathbf{1 0}$ is hydrolyzed by ceramidases and further reacylated with other acyl moieties. However, which of the 5 different ceramidases ${ }^{13}$ is responsible for the hydrolysis of $(2 S, 3 R)-\mathbf{1 0}$ is, so far, unknown.

A
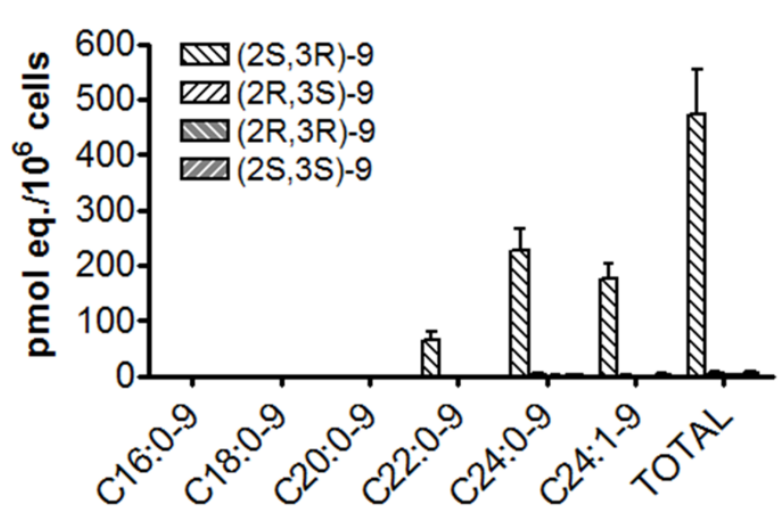

B
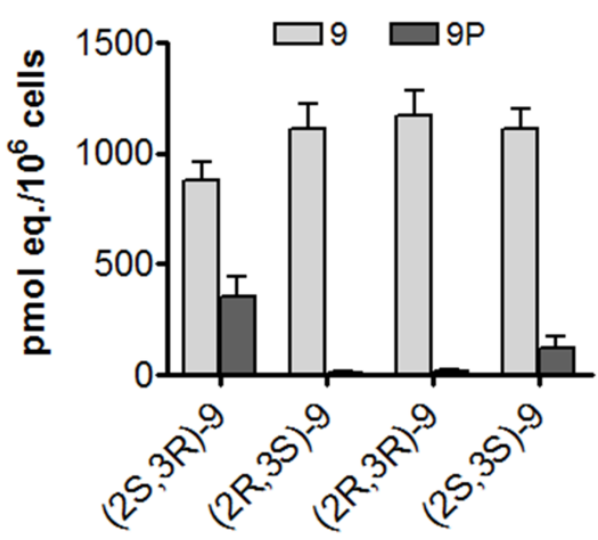

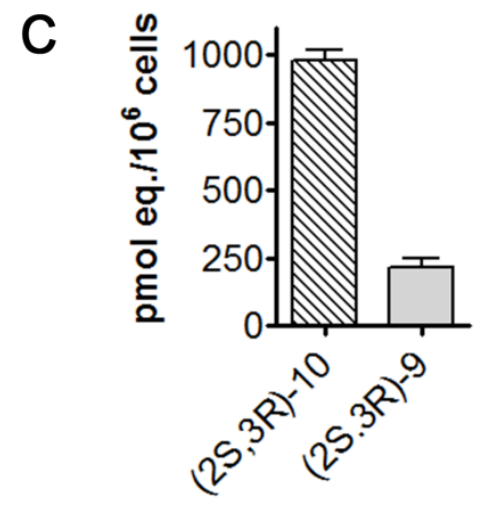

D

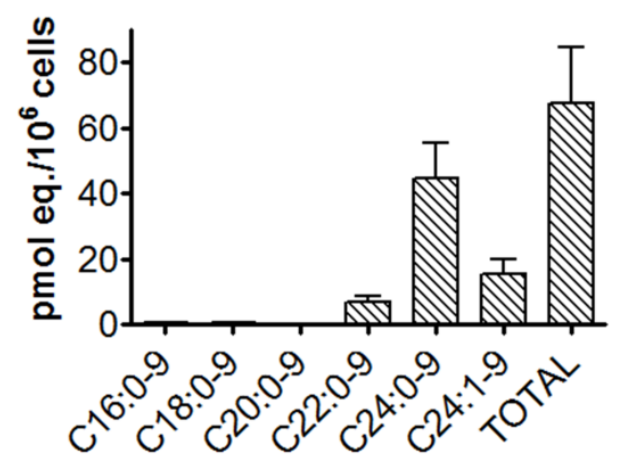


Fig. 2 Metabolism of compounds 9 and (2S,3R)-10 . Cells were incubated with: A-B, the four stereoisomers of $9(15 \mu \mathrm{M})$ and C-D, amide $(2 S, 3 R)-10(30 \mu \mathrm{M})$ for $24 \mathrm{~h}$. Lipid analysis was carried out by UPLC/TOF MS in ESI + (free bases and amides) or ESI - (phosphates). A-B, amounts of amides (A) and phosphates (B) present in cells treated with the different stereoisomers of 9; $(\mathrm{C})$ : amounts of incorporated amide $(2 S, 3 R)-\mathbf{1 0}$ and of its hydrolysis product $(2 S, 3 R)-\mathbf{9}$; (D): reacyclation products present in cells treated with amide $(2 S, 3 R)-\mathbf{1 0}$. Data were obtained from two independent experiments with triplicates.

\section{Effect on natural sphingolipids}

Cells treated with amino diols 9 did not give rise to any remarkable change in the natural sphingolipids content (data not shown). In contrast, cells exposed to amide $(2 S, 3 R)-10$ (30 $\mu \mathrm{M} / 24 \mathrm{~h}$ ) contained significantly lower total ceramide levels than vehicle treated controls, all the different $N$-acyl species being similarly reduced (Figure 3A). This reduction is translated into significantly lower levels of glucosylceramide (GlcCer) (Fig. 3B) and sphingomyelin (SM) (Fig. 3C).

A

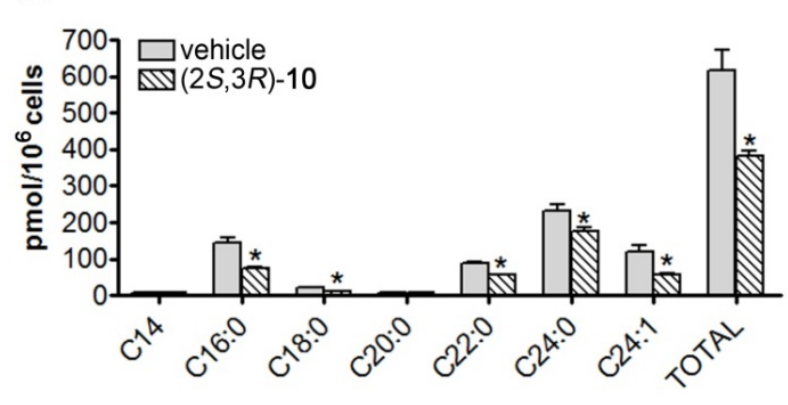

B

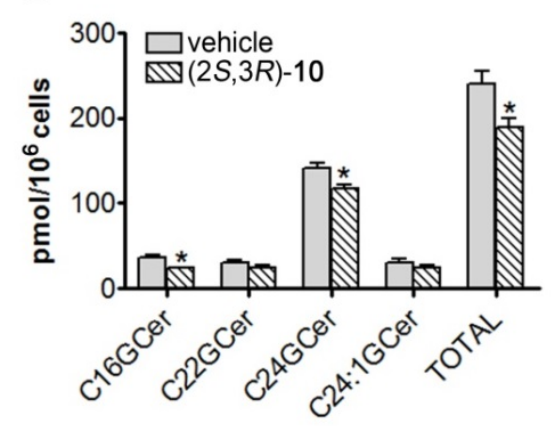

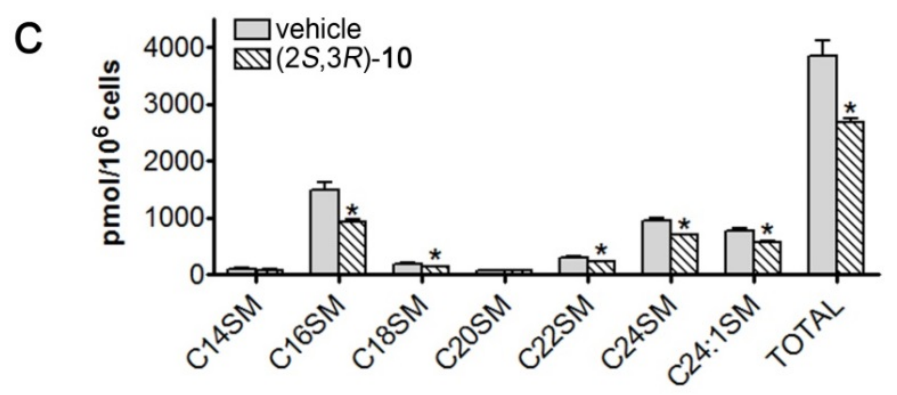

Fig. 3 Effect of (2S,3R)-10 on natural sphingolipids. Cells were incubated with $(2 S, 3 R)-\mathbf{1 0}$ $(30 \mu \mathrm{M} / 24 \mathrm{~h})$. Lipids were extracted and analyzed by UPLC/TOF MS. (A): amounts of 
natural ceramides (Cer); (B): amounts of natural glucosyl ceramides (GlcCer) and (C): amounts of natural sphingomyelins (SM). Data were obtained from 2 independent experiments with triplicates. Asterisks indicate statistical difference with vehicle (control) $(\mathrm{P}<0.05$. Unpaired, two-tail $t$ test $)$.

These results are consistent with inhibition of ceramide synthesis de novo. Since no increase in dihydroceramides was observed upon treatments (data not shown), dihydroceramide desaturase is not a likely candidate for inhibition. On the other hand, a decrease in CerS activity results in an increase in long chain bases and their phosphates. ${ }^{14,15}$ However, either sphinganine, sphingosine or their corresponding phosphates were not detected in extracts after cell treatment with amide $(2 S, 3 R)-\mathbf{1 0}$, arguing against inhibition of CerS. Furthermore, no accumulation of 3-ketosphinganine was found in extracts from cells incubated with $(2 S, 3 R)$ 10, which is against inhibition of 3-ketosphinganine reductase. Therefore, we suggest that serine palmitoyl transferase (SPT), the rate-limiting enzyme in ceramide synthesis de novo, is the likely target of $(2 S, 3 R)-\mathbf{1 0}$. Although this amide is $N$-deacylated to $(2 S, 3 R)-\mathbf{9}$, this amino alcohol has no effect on Cer, GlcCer and SM levels, which argues against its involvement in the observed inhibition. Collectively, our data support that $(2 S, 3 R)-\mathbf{1 0}$ could be responsible for the putative SPT inhibition.

\section{Conclusions}

The first stereoselective preparation of the four stereoisomers of quaternary 2-vinyl analogs of sphingosine has been achieved in a small number of steps and the effect of these compounds on basal sphingolipid metabolism in human A549 lung adenocarcinoma cells has been studied. A stereoselective borane-mediated addition of allene 1 to $(E)$-2-tridecenal very recently developed in our research group was used, giving only a single diastereomer $[(R, S)-7$ 
and $(S, R)-7]$. Resolution of enantiomers was readily accomplished by chromatography of the corresponding mixture of (R)-MPA diastereomeric esters followed by basic hydrolysis. Among the 2-vinyl sphingosines, only the $2 S, 3 R$ isomer was $N$-acylated to produce long chain ceramides, presumably by CerS2. The metabolic stability of these amides was studied with the corresponding $(2 S, 3 R)-N$-octanoyl amide 10, which confirmed the operation of deacylation and reacylation metabolic pathways. Interestingly, the effects of amide $\mathbf{1 0}$ on natural sphingolipidome are in agreement with the inhibition of SPT, the first enzyme of the de novo biosynthesis of sphingolipids.

\section{Experimental section}

\section{Chemistry}

All reactions involving moisture- or air-sensitive reagents were performed in oven-dried glassware under $\mathrm{N}_{2}$. Chemical shifts $(\delta)$ are quoted in parts per million and referenced for ${ }^{1} \mathrm{H}$ NMR to internal TMS (for $\mathrm{CDCl}_{3}$ ) or residual solvent peak d $2.50 \mathrm{ppm}$ (for DMSO- $d_{6}$ ). ${ }^{13} \mathrm{C}$ NMR are referenced to $\mathrm{CDCl}_{3}$ (d $\left.77.0 \mathrm{ppm}\right)$ or $\mathrm{DMSO}_{-} d_{6}$ (d $39.5 \mathrm{ppm}$ ). Column chromatography was performed on silica gel (Merck 230-400 mesh). HRMS analyses were recorded on a LC/MSD-TOF mass spectrometer.

3-Benzoyl-4-vinylideneoxazolidin-2-one (1). A solution of benzoyl isocyanate (4.20 g, 25.60 mmol) in anhydrous $\mathrm{CH}_{2} \mathrm{Cl}_{2}(20 \mathrm{~mL})$ was added to 2-butyn-1,4-diol $(1.00 \mathrm{~g}, 11.60 \mathrm{mmol})$ at 0 ${ }^{\circ} \mathrm{C}$ under $\mathrm{N}_{2}$ atmosphere. The mixture was stirred for 5 hours at $\mathrm{rt}$ and the solvent was removed. A solution of $\mathrm{Pd}_{2}(\mathrm{dba})_{3} \cdot \mathrm{CHCl}_{3}(0.055 \mathrm{~g}, 0.05 \mathrm{mmol})$ in anhydrous THF $(40 \mathrm{~mL})$ and triethylamine $(0.087 \mathrm{~mL}, 0.64 \mathrm{mmol})$ were added under $\mathrm{N}_{2}$ atmosphere. The mixture was stirred for $16 \mathrm{~h}$ at $\mathrm{rt}$ and filtered through a pad of Celite. The solid was washed with AcOEt. 
The solvent was removed and the crude residue was purified by column chromatography (hexanes/AcOEt 4:1) to afford $0.595 \mathrm{~g}(61 \%)$ of allene 1.

Compound 1, yellow solid; mp 102-103 ${ }^{\circ} \mathrm{C}$ (lit. $\left.{ }^{6} 101.2-103{ }^{\circ} \mathrm{C}\right) ; \mathbf{R}_{\mathbf{f}}($ hexanes/AcOEt 2:1) $=$ 0.35; ${ }^{1} \mathbf{H}$ NMR $\left(400 \mathrm{MHz}, \mathrm{CDCl}_{3}\right): \delta 7.68(\mathrm{~m}, 2 \mathrm{H}, \mathrm{Ar} H), 7.57(\mathrm{~m}, 1 \mathrm{H}, \mathrm{Ar} H), 7.45(\mathrm{~m}, 2 \mathrm{H}$, $\operatorname{Ar} H), 5.57\left(\mathrm{t}, 2 \mathrm{H}, J=4.7 \mathrm{~Hz},=\mathrm{CH}_{2}\right), 5.04\left(\mathrm{t}, 2 \mathrm{H}, J=4.7 \mathrm{~Hz}, \mathrm{CH}_{2} \mathrm{O}\right) ;{ }^{13} \mathbf{C}$ NMR $(101 \mathrm{MHz}$, $\left.\mathrm{CDCl}_{3}\right): \delta 193.6,167.3,151.9,132.8,129.2,128.1,128.0,103.9,90.4,63.9 ; \mathbf{I R}\left(\right.$ film, $\mathrm{cm}^{-1}$ ): 1792, 1689, 1331, 1308, 1157, 1068; HRMS (ESI+) calculated for $\mathrm{C}_{12} \mathrm{H}_{10} \mathrm{NO}_{3}[\mathrm{M}+\mathrm{H}]^{+}=$ 216.0655, found $=216.0651$.

\section{$(R S, E)-1-[(2-0 x 0-4-v i n y l o x a z o l i d i n-4-y l]$ tridec-2-en-1-yl benzoate $[( \pm)-6]$.}

A solution of the allene $1(1.24 \mathrm{~g}, 5.76 \mathrm{mmol}, 1.00 \mathrm{eq})$ in anhydrous $\mathrm{CH}_{2} \mathrm{Cl}_{2}(4 \mathrm{~mL})$ was added to a suspension of dicyclohexylborane ${ }^{16}(1.23 \mathrm{~g}, 6.91 \mathrm{mmol}, 1.2 \mathrm{eq})$ in $\mathrm{CH}_{2} \mathrm{Cl}_{2}(6 \mathrm{~mL})$ at $0{ }^{\circ} \mathrm{C}$ and under nitrogen atmosphere. The resulting mixture was stirred for 10 min at $0{ }^{\circ} \mathrm{C}$ and for $1 \mathrm{~h}$ at $\mathrm{rt}$. The resulting solution was then cooled to $-78{ }^{\circ} \mathrm{C}$, and $(E)$ - 2-tridecenal $(1.58$ $\mathrm{g}, 8.06 \mathrm{mmol}, 1.4 \mathrm{eq}$ ) was added. The reaction was stirred for $4 \mathrm{~h}$ at $\mathrm{rt}$, and was then quenched by addition of triethanolamine $(2.2 \mathrm{~g}, 2.5 \mathrm{eq})$. The resulting mixture was stirred for $1 \mathrm{~h}$ at $\mathrm{rt}$. Evaporation of the solvent under vacuum gave a crude that was purified by flash column cromatography (hexanes/AcOEt 7:3) to afford $1.78 \mathrm{~g}$ (4.30 mmol, 75\%) of adduct ( \pm )-6.

Compound ( \pm )-6, yellow oil; $\mathbf{R}_{\mathbf{f}}\left(\right.$ hexanes/AcOEt 3:2) $=0.60 ;{ }^{1} \mathbf{H}$ NMR $\left(400 \mathrm{MHz}, \mathrm{CDCl}_{3}\right)$ : $\delta$ 8.06-8.00 (m, 2H, ArH), 7.58-7.53 (m, 1H, ArH), 7.46-7.40 (m, 2H, ArH), 6.65 (bs, 1H, $\mathrm{NH}), 6.05-5.96(\mathrm{~m}, 2 \mathrm{H},=\mathrm{CH}, \mathrm{CHOBz}), 5.54-5.41(\mathrm{~m}, 3 \mathrm{H},=\mathrm{CHH}, \mathrm{CH}=\mathrm{CH}), 5.34(\mathrm{~d}, 1 \mathrm{H}, J=$ $10.8 \mathrm{~Hz},=\mathrm{CH} H), 4.46(\mathrm{~d}, 1 \mathrm{H}, J=8.7 \mathrm{~Hz}, \mathrm{OCHH}), 4.14(\mathrm{~d}, 1 \mathrm{H}, J=8.7 \mathrm{~Hz}, \mathrm{OCH} H), 2.05(\mathrm{td}$, $\left.2 \mathrm{H}, J=7.9,1.1 \mathrm{~Hz},=\mathrm{CHCH}_{2}\right), 1.38-1.19\left(\mathrm{~m}, 16 \mathrm{H}, \mathrm{C}_{8} H_{16}\right), 0.87\left(\mathrm{t}, 3 \mathrm{H}, J=6.9 \mathrm{~Hz}, \mathrm{CH}_{3}\right) ;{ }^{13} \mathbf{C}$ NMR $\left(101 \mathrm{MHz}, \mathrm{CDCl}_{3}\right): \delta 165.4,159.3,140.6,136.2,133.5,129.8,129.7,128.6,121.8$, $117.3,77.8,72.2,64.4,32.5,32.0,29.7,29.7,29.5,29.4,29.3,28.8,22.8,14.2 ;$ IR (ATR, $\mathrm{cm}^{-}$ 
$\left.{ }^{1}\right): 3240,2923,1755,1707,1263,709 ;$ HRMS (ESI + ) calculated for $\mathrm{C}_{25} \mathrm{H}_{35} \mathrm{NNaO}_{4}[\mathrm{M}+\mathrm{Na}]^{+}$ $=436.2458$, found $=436.2466$.

$(R S, E)-4-(1-h y d r o x y t r i d e c-2-e n-1-y l)-4-v i n y l o x a z o l i d i n-2-o n e ~[( \pm)-7]$.

A $3 \mathrm{M}$ solution of $\mathrm{EtMgBr}$ in $\mathrm{Et}_{2} \mathrm{O}(1.3 \mathrm{~mL}, 3 \mathrm{eq})$ was dropwise added to a solution of compound $( \pm)-6(537 \mathrm{mg}, 1.30 \mathrm{mmol}, 1 \mathrm{eq})$ in dry THF $(8 \mathrm{~mL})$ at $0{ }^{\circ} \mathrm{C}$. The reaction was followed by TLC (hexanes/AcOEt 3:2). After $2 \mathrm{~h}$ at $0{ }^{\circ} \mathrm{C}$, the reaction was partitioned by addition of $p \mathrm{H} 7$ buffer and $\mathrm{CH}_{2} \mathrm{Cl}_{2}$. The organic layer was washed with additional $p \mathrm{H} 7$ buffer solution, dried over $\mathrm{MgSO}_{4}$ and filtered. The evaporation of the solvent under vacuum gave a crude which was purified by flash column cromatography (hexanes/AcOEt 3:2) to afford compound ( \pm )-7 (341 mg, $1.11 \mathrm{mmol}, 85 \%)$ :

Compound ( \pm )-7, mp $=70-2{ }^{\circ} \mathrm{C} ; \mathbf{R}_{\mathbf{f}}($ hexanes/AcOEt $3: 2)=0.34 ;{ }^{1} \mathbf{H}$ NMR $(400 \mathrm{MHz}$, $\left.\mathrm{CDCl}_{3}\right): \delta 6.70(\mathrm{bs}, 1 \mathrm{H}, \mathrm{N} H), 5.92(\mathrm{dd}, 1 \mathrm{H}, J=17.3,10.7 \mathrm{~Hz},=\mathrm{CH}), 5.80(\mathrm{dt}, 1 \mathrm{H}, J=15.4$, $\left.6.7 \mathrm{~Hz},=\mathrm{CHCH}_{2}\right), 5.39-5.25\left(\mathrm{~m}, 3 \mathrm{H}, \mathrm{CH}=\mathrm{CH},=\mathrm{CH}_{2}\right), 4.44(\mathrm{~d}, 1 \mathrm{H}, J=8.5 \mathrm{~Hz}, \mathrm{OCHH}), 4.05$ (d, 1H, $J=7.1 \mathrm{~Hz}, \mathrm{CHOH}), 4.01(\mathrm{~d}, 1 \mathrm{H}, J=8.5 \mathrm{~Hz}, \mathrm{OCH}), 3.68(\mathrm{bs}, 1 \mathrm{H}, \mathrm{OH}), 2.01$ (q, 2H, $\left.J=6.9 \mathrm{~Hz},=\mathrm{CHCH}_{2}\right), 1.37-1.19\left(\mathrm{~m}, 16 \mathrm{H}, \mathrm{C}_{8} H_{16}\right), 0.85\left(\mathrm{t}, 3 \mathrm{H}, J=6.9 \mathrm{~Hz}, \mathrm{CH}_{3}\right) ;{ }^{13} \mathbf{C ~ N M R}$ $\left(101 \mathrm{MHz} \mathrm{CDCl}_{3}\right): \delta 160.2,137.1,136.9,125.6,116.4,75.9,71.7,65.5,32.5,32.0,29.7$, 29.5, 29.4, 29.3, 29.1, 22.7, 14.2; IR (ATR, $\left.\mathrm{cm}^{-1}\right): 3287,2922,2851,1742,1042,936$; HRMS $\left(\mathrm{ESI}+\right.$ ) calculated for $\mathrm{C}_{18} \mathrm{H}_{32} \mathrm{NO}_{3}[\mathrm{M}+\mathrm{H}]^{+}=310.2377$, found $=310.2384$.

$(4 S R, 5 R S, E)-5-($ dodec-1-en-1-yl)-4-(hydroxymethyl)-4-vinyloxazolidin-2-one [( \pm )-7'].

A solution of $\mathrm{NaOH}(0.04 \mathrm{~g}, 1.0 \mathrm{mmol})$ in $9: 1 \mathrm{MeOH} / \mathrm{H}_{2} \mathrm{O}(1 \mathrm{~mL})$ was added to a stirred solution of compound $( \pm)-6(300 \mathrm{mg}, 0.73 \mathrm{mmol}, 1 \mathrm{eq})$ in $9: 1 \mathrm{MeOH} / \mathrm{H}_{2} \mathrm{O}(10 \mathrm{~mL})$ at r.t. The advance of the reaction was followed by TLC (hexanes/AcOEt 3:2). After $6 \mathrm{~h}$, the mixture was heated at $50{ }^{\circ} \mathrm{C}$ for additional $3 \mathrm{~h}$ and no more changes was observed (TLC). The reaction was partitioned by addition of a saturated aqueous solution of $\mathrm{NH}_{4} \mathrm{Cl}(20 \mathrm{~mL})$ and $\mathrm{CH}_{2} \mathrm{Cl}_{2}(20$ 
$\mathrm{mL})$. The phases were decanted and the aqueous phase was washed with more $\mathrm{CH}_{2} \mathrm{Cl}_{2}(2 \times 10$ $\mathrm{mL}$ ). The combined organic portions were dried over anhydrous $\mathrm{MgSO}_{4}$, filtered, and concentrated under reduced pressure. The residue was purified by column chromatography using silica gel (hexanes/AcOEt 7:3) to afford ( \pm )-7' (0.112 g, 50\%) and ( \pm )-7 (0.072 g, 32\%).

Compound ( \pm )-7': colourless oil; $\mathbf{R}_{\mathbf{f}}($ hexanes/AcOEt $3: 2)=0.18 ;{ }^{1} \mathbf{H}$ NMR $(400 \mathrm{MHz}$, $\left.\mathrm{CDCl}_{3}\right): \delta 6.70($ broad band, $1 \mathrm{H}, \mathrm{NH}), 5.86\left(\mathrm{dt}, 1 \mathrm{H}, J=15.2,6.7 \mathrm{~Hz},=\mathrm{CHCH}_{2}\right), 5.74(\mathrm{dd}, 1 \mathrm{H}$, $J=17.4,10.8 \mathrm{~Hz},=\mathrm{CH}), 5.72-5.66(\mathrm{~m}, 1 \mathrm{H}, \mathrm{C} H=\mathrm{CH}), 5.37(\mathrm{dd}, 1 \mathrm{H}, J=17.4,0.5 \mathrm{~Hz},=\mathrm{C} H \mathrm{H})$, $5.27(\mathrm{dd}, 1 \mathrm{H}, J=10.8,0.5 \mathrm{~Hz},=\mathrm{CH} H), 4.65(\mathrm{~d}, 1 \mathrm{H}, J=8.4 \mathrm{~Hz}, \mathrm{OCH}), 3.71(\mathrm{~d}, 1 \mathrm{H}, J=12.0$ $\mathrm{Hz}, \mathrm{CHHOH}), 3.56(\mathrm{~d}, 1 \mathrm{H}, J=12.0 \mathrm{~Hz}, \mathrm{CH} H \mathrm{OH}), 2.12-2.06\left(\mathrm{~m}, 2 \mathrm{H},=\mathrm{CHCH}_{2}\right), 1.29-1.23$ $\left(\mathrm{m}, 16 \mathrm{H}, \mathrm{C}_{8} H_{16}\right), 0.87\left(\mathrm{t}, 3 \mathrm{H}, J=6.5 \mathrm{~Hz}, \mathrm{CH}_{3}\right) ;{ }^{13} \mathbf{C}$ NMR $\left(101 \mathrm{MHz}, \mathrm{CDCl}_{3}\right): \delta 160.3,140.0$, $135.9,121.7,117.2,86.6,66.6,64.6,32.4,32.0,29.7,29.7,29.6,29.5,29.3,28.9,22.8,14.2$; IR (ATR, $\left.\mathrm{cm}^{-1}\right): 3277,2922,2853,1736,1350,976$; HRMS (ESI + ) calculated for $\mathrm{C}_{18} \mathrm{H}_{32} \mathrm{NO}_{3}[\mathrm{M}+\mathrm{H}]^{+}=310.2377$, found $=310.2384$.

\section{Isomerization of $( \pm)-7$}

A solution of Dess-Martin periodinane (DMP) (1.930 g, $4.414 \mathrm{mmol}, 1.1 \mathrm{eq})$ in dry $\mathrm{CH}_{2} \mathrm{Cl}_{2}$ $(10 \mathrm{~mL})$ was dropwise added to a stirred solution of $( \pm)-7(1.240 \mathrm{~g}, 4.007 \mathrm{mmol}, 1 \mathrm{eq})$ in dry $\mathrm{CH}_{2} \mathrm{Cl}_{2}(10 \mathrm{~mL})$ at r.t. The course of the reaction was followed by TLC. After $30 \mathrm{~min}$, the reaction was quenched by adding sat. $\mathrm{NaHCO}_{3}$ aqueous solution $(10 \mathrm{~mL})$ and solid $\mathrm{Na}_{2} \mathrm{~S}_{2} \mathrm{O}_{3}$ $(0.30 \mathrm{~g})$. The mixture was extracted with $\mathrm{CH}_{2} \mathrm{Cl}_{2}(5 \times 10 \mathrm{~mL})$ and the combined organic layers were dried over anhydrous $\mathrm{MgSO}_{4}$, filtered, and concentrated under reduced pressure to give $1.180 \mathrm{~g}$ of crude ketone $( \pm)-\mathbf{1 1}\left[\mathbf{R}_{\mathbf{f}}(\right.$ hexanes/AcOEt 3:2) $=0.58]$. A mixture of $\mathrm{NaBH}_{4}$ (0.443 g, $11.710 \mathrm{mmol}, 3 \mathrm{eq})$ and $\mathrm{CeCl}_{3}: 7 \mathrm{H}_{2} \mathrm{O}(2.90 \mathrm{~g}, 7.807 \mathrm{mmol}, 2 \mathrm{eq})$ was added to a solution of the crude ketone $(1.180 \mathrm{~g})$ in THF $(20 \mathrm{~mL})$ and EtOH $(60 \mathrm{~mL})$ at $0{ }^{\circ} \mathrm{C}$. After $6 \mathrm{~h}$, the reaction was quenched by addition of a sat. solution of $\mathrm{NH}_{4} \mathrm{Cl}(40 \mathrm{~mL})$ and water $(60$ $\mathrm{mL})$. The mixture was extracted with $\mathrm{CH}_{2} \mathrm{Cl}_{2}(5 \times 20 \mathrm{~mL})$ and the combined organic layers 
were dried $\left(\mathrm{MgSO}_{4}\right)$, filtered, and concentrated under reduced pressure. The ${ }^{1} \mathrm{H}$ NMR of the residue showed a roughly 1:1 mixture of isomers $( \pm)-7$ and its racemic diastereomer $(0.781 \mathrm{~g}$, 2.44 mmol, 63\% two-steps yield).

\section{Typical procedure for the preparation of the $(R)$-MPA esters 8.}

A solution of $(R)$-methoxyphenylacetic acid [(R)-MPA, $0.135 \mathrm{~g}, 0.81 \mathrm{mmol}, 1.4 \mathrm{eq}]$ and 1ethyl-3-(3-dimethylaminopropyl)carbodiimide (EDC, $0.167 \mathrm{~g}, 0.87 \mathrm{mmol}$ ) in $\mathrm{CH}_{2} \mathrm{Cl}_{2}(10 \mathrm{~mL})$ was stirred at $0{ }^{\circ} \mathrm{C}$ for $30 \mathrm{~min}$. Then, a solution of $( \pm)-7(0.180 \mathrm{~g}, 0.58 \mathrm{mmol})$ and a catalytic amount of 4-dimethylaminopyridine (DMAP, $0.010 \mathrm{~g})$ in $\mathrm{CH}_{2} \mathrm{Cl}_{2}(10 \mathrm{~mL})$ was added and the solution was stirred for $2 \mathrm{~h}$ at r.t. The reaction was quenched by addition of $2 \mathrm{M} \mathrm{HCl}(10 \mathrm{~mL})$ and the organic phase was washed with more $2 \mathrm{M} \mathrm{HCl}(10 \mathrm{~mL})$, sat. $\mathrm{NaHCO}_{3}(10 \mathrm{~mL})$ and brine $(10 \mathrm{~mL})$. The combined organic portions were dried over anhydrous $\mathrm{MgSO}_{4}$, filtered, and concentrated under reduced pressure. The crude product was purified by column chromatography in silica gel (4:1 hexanes/ EtOAc) to afford $0.117 \mathrm{~g}(0.27 \mathrm{mmol}, 46 \%)$ of $(2 S, 3 R)-8$ and $0.120 \mathrm{~g}(0.28 \mathrm{mmol}, 47 \%)$ of $(2 R, 3 S)-8$.

$(2 S, 3 R)-8$ : colourless oil; $\mathbf{R}_{\mathbf{f}}($ hexanes/AcOEt $3: 2)=0.82 ;[\boldsymbol{\alpha}]_{\mathbf{D}}{ }^{25}=+6.7\left(c=1.0, \mathrm{CHCl}_{3}\right) ;{ }^{\mathbf{1}} \mathbf{H}$ NMR $\left(400 \mathrm{MHz}, \mathrm{CDCl}_{3}\right): \delta 7.42-7.30(\mathrm{~m}, 5 \mathrm{H}, \mathrm{Ar} H), 5.91(\mathrm{dt}, 1 \mathrm{H}, J=14.7,6.8 \mathrm{~Hz}$, $\left.=\mathrm{CHCH}_{2}\right), 5.72(\mathrm{bs}, 1 \mathrm{H}, \mathrm{NH}), 5.62(\mathrm{dd}, 1 \mathrm{H}, J=17.3,10.7 \mathrm{~Hz},=\mathrm{CH}), 5.36-5.23(\mathrm{~m}, 2 \mathrm{H}$, $\mathrm{OCHCH=}), 5.06(\mathrm{~d}, 1 \mathrm{H}, J=17.2 \mathrm{~Hz},=\mathrm{CHH}), 5.06(\mathrm{~d}, 1 \mathrm{H}, J=10.7 \mathrm{~Hz},=\mathrm{CH} H), 4.73(\mathrm{~s}, 1 \mathrm{H}$, CHPh), $3.96(\mathrm{~d}, 1 \mathrm{H}, J=8.8 \mathrm{~Hz}, \mathrm{OCHH}), 3.75(\mathrm{~d}, 1 \mathrm{H}, J=8.8 \mathrm{~Hz}, \mathrm{OCH} H), 3.38(\mathrm{~s}, 3 \mathrm{H}$, $\left.\mathrm{OCH}_{3}\right), 2.07-1.98\left(\mathrm{~m}, 2 \mathrm{H},=\mathrm{CHCH}_{2}\right), 1.38-1.19\left(\mathrm{~m}, 16 \mathrm{H}, \mathrm{C}_{8} H_{16}\right), 0.87(\mathrm{t}, 3 \mathrm{H}, J=6.9 \mathrm{~Hz}$, $\left.\mathrm{CH}_{3}\right) ;{ }^{13} \mathrm{C}$ NMR (101 MHz, $\left.\mathrm{CDCl}_{3}\right): \delta 169.4,158.4,141.3,136.2,135.5,129.1,128.9,127.3$, $121.3,116.9,82.5,77.8,72.0,63.9,57.5,32.5,32.0,29.7,29.7,29.5,29.5,29.3,28.7,22.8$, 14.2; IR (ATR, cm ${ }^{-1}$ ): 2923, 2853, 1748, 1169, 1108, 752; HRMS (ESI+) calculated for $\mathrm{C}_{27} \mathrm{H}_{40} \mathrm{NO}_{5}[\mathrm{M}+\mathrm{H}]^{+}=458.2901$, found $=458.2913$. 
$(2 R, 3 S)-8$ : colourless oil; $\mathbf{R}_{\mathbf{f}}\left(\right.$ hexanes/AcOEt 3:2) $=0.69 ;[\boldsymbol{\alpha}]_{\mathbf{D}}{ }^{25}=-71.0\left(c=1.0, \mathrm{CHCl}_{3}\right) ;{ }^{1} \mathbf{H}$ NMR (400 MHz, $\left.\mathrm{CDCl}_{3}\right): \delta 7.42-7.32(\mathrm{~m}, 5 \mathrm{H}, \mathrm{ArH}), 5.90(\mathrm{bs}, 1 \mathrm{H}, \mathrm{NH}), 5.83(\mathrm{dd}, 1 \mathrm{H}, J=$ $17.2,10.7 \mathrm{~Hz},=\mathrm{CH}), 5.59\left(\mathrm{dt}, 1 \mathrm{H}, J=14.5,6.8 \mathrm{~Hz},=\mathrm{CHCH}_{2}\right), 5.33-5.26(\mathrm{~m}, 3 \mathrm{H}, \mathrm{OCHCH}=$, $\left.=\mathrm{CH}_{2}\right), 5.22-5.13(\mathrm{~m}, 1 \mathrm{H}, \mathrm{CH}=\mathrm{CH}), 4.76(\mathrm{~s}, 1 \mathrm{H}, \mathrm{OCHPh}), 4.23(\mathrm{~d}, 1 \mathrm{H}, J=8.8 \mathrm{~Hz}, \mathrm{OCHH})$, $4.00(\mathrm{~d}, 1 \mathrm{H}, J=8.8 \mathrm{~Hz}, \mathrm{OCH} H), 3.39\left(\mathrm{~s}, 3 \mathrm{H}, \mathrm{OCH}_{3}\right), 1.94-1.87\left(\mathrm{~m}, 2 \mathrm{H},=\mathrm{CHCH}_{2}\right), 1.34-1.14$ $\left(\mathrm{m}, 16 \mathrm{H}, \mathrm{C}_{8} H_{16}\right), 0.88\left(\mathrm{t}, 3 \mathrm{H}, J=6.9 \mathrm{~Hz}, \mathrm{CH}_{3}\right) ;{ }^{13} \mathbf{C}$ NMR $\left(101 \mathrm{MHz}, \mathrm{CDCl}_{3}\right): \delta 169.6,158.4$, $140.6,136.0,135.9,129.1,128.8,127.3,120.8,117.3,82.6,77.4,71.8,63.9,57.5,32.4,32.1$, 29.8, 29.7, 29.5, 29.5, 29.2, 28.7, 22.8, 14.3; IR (ATR, $\left.\mathrm{cm}^{-1}\right): 2923,2858,1748,1169,1108$ 752; HRMS (ESI+) calculated for $\mathrm{C}_{27} \mathrm{H}_{40} \mathrm{NO}_{5}[\mathrm{M}+\mathrm{H}]^{+}=458.2901$, found $=458.2908$.

$(2 S, 3 S)-8$ : colourless oil; $\mathbf{R}_{\mathbf{f}}\left(\right.$ hexanes/AcOEt 3:2) $=0.40 ;[\boldsymbol{\alpha}]_{\mathbf{D}}{ }^{25}=+6.5\left(c=1.0, \mathrm{CHCl}_{3}\right) ;{ }^{1} \mathbf{H}$ NMR (400 MHz, $\left.\mathrm{CDCl}_{3}\right): \delta$ 7.50-7.31 (m, 5H, $\left.\mathrm{ArH}\right), 5.81(\mathrm{dd}, 1 \mathrm{H}, J=17.2,10.7 \mathrm{~Hz}$ $\left.\mathrm{CH}_{2}=\mathrm{CH}\right), 5.78(\mathrm{bs}, 1 \mathrm{H}, \mathrm{NH}), 5.39-5.30\left(\mathrm{~m}, 3 \mathrm{H},=\mathrm{CH}_{2}, \mathrm{CHOCO}\right), 5.24(\mathrm{dt}, 1 \mathrm{H}, J=15.6,6.7$ $\left.\mathrm{Hz},=\mathrm{CHCH}_{2}\right), 5.09(\mathrm{dd}, 1 \mathrm{H}, J=15.5,6.0 \mathrm{~Hz}, \mathrm{CHCH}=), 4.84(\mathrm{~s}, 1 \mathrm{H}, \mathrm{CHOMe}), 4.27(\mathrm{~d}, 1 \mathrm{H}, J$ $=8.8 \mathrm{~Hz}, \mathrm{OCHH}), 4.07(\mathrm{~d}, 1 \mathrm{H}, J=8.8 \mathrm{~Hz}, \mathrm{OCH} H), 3.41\left(\mathrm{~s}, 3 \mathrm{H}, \mathrm{OCH}_{3}\right), 1.80(\mathrm{q}, 2 \mathrm{H}, J=6.0$ $\left.\mathrm{Hz},=\mathrm{CHCH}_{2}\right), 1.33-1.07\left(\mathrm{~m}, 16 \mathrm{H}, \mathrm{C}_{8} H_{16}\right), 0.88\left(\mathrm{t}, 3 \mathrm{H}, J=6.8 \mathrm{~Hz}, \mathrm{CH}_{3}\right){ }^{13} \mathbf{C}$ NMR $(101$ $\left.\mathrm{MHz}, \mathrm{CDCl}_{3}\right): \delta 169.6,158.9,138.3,136.0,135.5,129.0,128.8,127.5,120.7,117.4,82.3$, $77.1,64.0,57.4,32.3,32.0,29.8,29.7,29.5,29.5,29.1,28.7,22.8,14.3$; IR (ATR, $\left.\mathrm{cm}^{-1}\right)$ : 2923, 2853, 1748, 1169, 1108, 752; HRMS (ESI+) calculated for $\mathrm{C}_{27} \mathrm{H}_{40} \mathrm{NO}_{5}[\mathrm{M}+\mathrm{H}]^{+}=$ 458.2901, found $=458.2895$.

$(2 R, 3 R)-\mathbf{8}$ : colourless oil; $\mathbf{R}_{\mathbf{f}}\left(\right.$ hexanes/AcOEt 3:2) $=0.62 ;[\boldsymbol{\alpha}]_{\mathbf{D}}{ }^{\mathbf{2 5}}=-98.7\left(c=1.0, \mathrm{CHCl}_{3}\right) ;{ }^{1} \mathbf{H}$ NMR $\left(400 \mathrm{MHz}, \mathrm{CDCl}_{3}\right): \delta$ 7.49-7.32 (m, 5H, $\left.\mathrm{ArH}\right), 5.82(\mathrm{dt}, 1 \mathrm{H}, J=15.2,6.8 \mathrm{~Hz}$, $\left.=\mathrm{CHCH}_{2}\right), 5.62\left(\mathrm{dd}, 1 \mathrm{H}, J=17.2,10.7 \mathrm{~Hz}, \mathrm{CH}_{2}=\mathrm{CH}\right), 5.42(\mathrm{bs}, 1 \mathrm{H}, \mathrm{NH}), 5.29(\mathrm{dd}, 1 \mathrm{H}, J=$ 15.3, 7.2 Hz, $\mathrm{CHCH}=)$, 5.25-5.11 (m, 3H, =CH2, CHOCO), 4.78 (s, 1H, CHOMe), 3.93 (d, $1 \mathrm{H}, J=8.8 \mathrm{~Hz}, \mathrm{CHHO}), 3.86(\mathrm{~d}, 1 \mathrm{H}, J=8.8 \mathrm{~Hz}, \mathrm{CH} H \mathrm{O}), 3.39\left(\mathrm{~s}, 3 \mathrm{H}, \mathrm{OCH}_{3}\right), 2.01(\mathrm{q}, 2 \mathrm{H}, J$ $\left.=7.1 \mathrm{~Hz},=\mathrm{CHCH}_{2}\right), 1.35-1.17\left(\mathrm{~m}, 16 \mathrm{H}, \mathrm{C}_{8} H_{16}\right), 0.87\left(\mathrm{t}, 3 \mathrm{H}, J=6.8 \mathrm{~Hz}, \mathrm{CH}_{3}\right) ;{ }^{13} \mathbf{C} \mathbf{~ N M R}$ 
$\left(101 \mathrm{MHz}, \mathrm{CDCl}_{3}\right): \delta 169.6,158.4,139.6,136.2,135.5,129.3,129.0,127.3,121.3,117.0$, $82.4,77.8,71.7,63.7,57.4,32.5,32.0,29.7,29.7,29.5,29.4,29.2,28.8,22.8,14.2$; IR (ATR, $\left.\mathrm{cm}^{-1}\right): 2923,2853,1748,1169,1108,752$; HRMS (ESI+) calculated for $\mathrm{C}_{27} \mathrm{H}_{40} \mathrm{NO}_{5}[\mathrm{M}+\mathrm{H}]^{+}$ $=458.2901$, found $=458.2891$.

\section{Typical procedure for hydrolysis of the (R)-MPA esters 8 to amino diols 9.}

A solution of ester $(2 S, 3 R)-8(0.170 \mathrm{~g}, 0.372 \mathrm{mmol})$ in a $1: 1 \mathrm{EtOH} / 2 \mathrm{M}$ aq. $\mathrm{NaOH}$ mixture (6 $\mathrm{mL}$ ) was heated to reflux. The progress of the reaction was followed by TLC (hexanes/AcOEt 3:2). After $20 \mathrm{~h}$, the $\mathrm{EtOH}$ was evaporated under vacuum and the aqueous residue was extracted with $\mathrm{CH}_{2} \mathrm{Cl}_{2}(4 \times 10 \mathrm{~mL})$. The combined organic portions were dried over anhydrous $\mathrm{MgSO}_{4}$, filtered, and concentrated under reduced pressure. The crude product was purified by column chromatography in silica gel $\left(9: 1 \mathrm{CH}_{2} \mathrm{Cl}_{2} / \mathrm{MeOH}\right)$ to afford $0.099 \mathrm{~g}(0.35$ mmol, 94\%) of $(2 S, 3 R)-9$.

$(2 S, 3 R)-9$ : colourless oil; $[\boldsymbol{\alpha}]_{\mathbf{D}}{ }^{25}=+14.4\left(c=1.0, \mathrm{CHCl}_{3}\right) ;{ }^{1} \mathbf{H}$ NMR $\left(400 \mathrm{MHz}, \mathrm{CDCl}_{3}\right): \delta$ $5.97\left(\mathrm{dd}, 1 \mathrm{H}, J=17.7,10.7 \mathrm{~Hz}, \mathrm{CH}=\mathrm{CH}_{2}\right), 5.74\left(\mathrm{dt}, 1 \mathrm{H}, J=15.4,6.7 \mathrm{~Hz},=\mathrm{CHCH}_{2}\right), 5.45$ $(\mathrm{dd}, 1 \mathrm{H}, J=15.4,7.6 \mathrm{~Hz}, \mathrm{CHCH} H), 5.33-5.24\left(\mathrm{~m}, 2 \mathrm{H},=\mathrm{CH}_{2}\right), 3.96(\mathrm{~d}, 1 \mathrm{H}, J=7.6 \mathrm{~Hz}$, $\mathrm{CHOH}), 3.71(\mathrm{~d}, 1 \mathrm{H}, J=11.0 \mathrm{~Hz}, \mathrm{OCHH}), 3.43(\mathrm{~d}, 1 \mathrm{H}, J=10.9 \mathrm{~Hz}, \mathrm{OCH} H), 2.21(\mathrm{bs}, 4 \mathrm{H}$, $\left.\mathrm{NH}_{2}, 2 \mathrm{xOH}\right), 2.04\left(\mathrm{q}, 2 \mathrm{H}, J=7.2 \mathrm{~Hz},=\mathrm{CHCH}_{2}\right), 1.44-1.14\left(\mathrm{~m}, 16 \mathrm{H}, \mathrm{C}_{8} H_{16}\right), 0.87(\mathrm{t}, 3 \mathrm{H}, J=$ $\left.6.8 \mathrm{~Hz}, \mathrm{CH}_{3}\right) ;{ }^{13} \mathrm{C}$ NMR (101 MHz, $\left.\mathrm{CDCl}_{3}\right): \delta 140.0,136.0,127.7,115.8,77.0,66.7,60.7$, $32.5,32.1,29.8,29.6,29.5,29.4,29.4,29.3,22.8,14.3$; HRMS (ESI+) calculated $\mathrm{C}_{17} \mathrm{H}_{34} \mathrm{NO}_{2}$ $[\mathrm{M}+\mathrm{H}]^{+}=284.2584$, found $=284.2581$.

$(2 R, 3 S)-9:[\alpha]_{\mathbf{D}}{ }^{25}=-15.1\left(c=1.0, \mathrm{CHCl}_{3}\right) ;$ HRMS $(\mathrm{ESI}+)$ calculated $\mathrm{C}_{17} \mathrm{H}_{34} \mathrm{NO}_{2}[\mathrm{M}+\mathrm{H}]^{+}=$ 284.2584 , found $=284.2584$.

$(2 R, 3 R)-9: \operatorname{mp} 63-5{ }^{\circ} \mathrm{C} ;[\boldsymbol{\alpha}]_{\mathbf{D}}{ }^{25}=-7.0\left(c=1.1, \mathrm{CHCl}_{3}\right) ;{ }^{1} \mathbf{H}$ NMR $\left(400 \mathrm{MHz}, \mathrm{CDCl}_{3}\right): \delta 5.82$ $\left(\mathrm{dd}, 1 \mathrm{H}, J=17.7,10.8 \mathrm{~Hz}, \mathrm{CH}_{2}=\mathrm{CH}\right), 5.73\left(\mathrm{dt}, 1 \mathrm{H}, J=15.2,7.1 \mathrm{~Hz},=\mathrm{CHCH}_{2}\right), 5.41(\mathrm{dd}, 1 \mathrm{H}$, $J=15.4,6.6 \mathrm{~Hz}, \mathrm{CHCH}=), 5.31-5.25\left(\mathrm{~m}, 2 \mathrm{H},=\mathrm{CH}_{2}\right), 4.10(\mathrm{~d}, 1 \mathrm{H}, J=6.3 \mathrm{~Hz}, \mathrm{CHOH}), 3.65$ 
$(\mathrm{d}, 1 \mathrm{H}, J=11.0 \mathrm{~Hz}, \mathrm{OCHH}), 3.48(\mathrm{~d}, 1 \mathrm{H}, J=11.0 \mathrm{~Hz}, \mathrm{OCH} H), 2.03(\mathrm{q}, 2 \mathrm{H}, J=7.1 \mathrm{~Hz}$, $\left.=\mathrm{CHCH}_{2}\right), 1.38-1.20\left(\mathrm{~m}, 16 \mathrm{H}, \mathrm{C}_{8} H_{16}\right), 0.88\left(\mathrm{t}, 3 \mathrm{H}, J=6.9 \mathrm{~Hz}, \mathrm{CH}_{3}\right) ;{ }^{13} \mathbf{C} \mathbf{N M R}(101 \mathrm{MHz}$, $\left.\mathrm{CDCl}_{3}\right): \delta 138.6,134.7,127.5,116.0,75.6,67.3,61.3,32.4,32.1,29.6,29.5,29.3,29.3,29.2$ 29.1, 22.7, 14.1; HRMS (ESI+) calculated $\mathrm{C}_{17} \mathrm{H}_{34} \mathrm{NO}_{2}[\mathrm{M}+\mathrm{H}]^{+}=284.2584$, found $=$ 284.2581

For $(2 S, 3 S)-9:[\alpha]_{\mathbf{D}}{ }^{25}=+7.6\left(c=1.0, \mathrm{CHCl}_{3}\right)$; HRMS $(\mathrm{ESI}+)$ calculated $\mathrm{C}_{17} \mathrm{H}_{34} \mathrm{NO}_{2}[\mathrm{M}+\mathrm{H}]^{+}$ $=284.2584$, found $=284.2583$.

\section{(3'S,4'R,E)-N-(4-hydroxy-3-(hydroxymethyl)hexadeca-1,5-dien-3-yl)octanamide (11)}

A solution of octanoic acid $(7.2 \mathrm{mg}, 0.05 \mathrm{mmol})$ and EDC (10 $\mathrm{mg}, 0.05 \mathrm{mmol})$ in anhydrous $\mathrm{CH}_{2} \mathrm{Cl}_{2}(1 \mathrm{~mL})$ was stirred for $30 \mathrm{~min}$. To this mixture, a solution of the starting alcohol $(2 S, 3 R)-9(10 \mathrm{mg}, 0.035 \mathrm{mmol})$ and DMAP (5 mg, $0.04 \mathrm{mmol})$ in $\mathrm{CH}_{2} \mathrm{Cl}_{2}(1 \mathrm{~mL})$ was added dropwise. After stirring $15 \mathrm{~h}$ at $\mathrm{rt}$, the mixture was diluted with $\mathrm{CH}_{2} \mathrm{Cl}_{2}(5 \mathrm{~mL})$ and washed successively with $\mathrm{HCl} 1 \mathrm{~N}$, water, $\mathrm{NaHCO}_{3}$ and water $(3 \mathrm{~mL}$ each). The organic layer was dried over $\mathrm{MgSO}_{4}$, filtered and concentrated under reduced pressure. The resulting crude was purified by flash chromatography (Hexanes-EtOAc 8:2), to yield amide $\mathbf{1 0}$ (10.7 $\mathrm{mg}, 75 \%)$.

${ }^{1} \mathbf{H}$ NMR $\left(400 \mathrm{MHz}, \mathrm{CDCl}_{3}\right) \delta 6.04($ br s, $1 \mathrm{H}, \mathrm{NH}), 5.93(\mathrm{dd}, J=17.3,10.7 \mathrm{~Hz}, 1 \mathrm{H},=\mathrm{CH})$, $5.79-5.66\left(\mathrm{~m}, 1 \mathrm{H},=\mathrm{CHC}_{10} \mathrm{H}_{21}\right), 5.38(\mathrm{ddd}, J=7.6,7.0,1.7 \mathrm{~Hz}, 1 \mathrm{H},=\mathrm{CHCHOH}), 5.24(\mathrm{dd}, J$ $\left.=82.8,14.0 \mathrm{~Hz}, 2 \mathrm{H},=\mathrm{CH}_{2}\right), 4.45\left(\right.$ br s, $\left.1 \mathrm{H}, \mathrm{CH}_{2} \mathrm{OH}\right), 4.07(\mathrm{~d}, J=7.4 \mathrm{~Hz}, 1 \mathrm{H}, \mathrm{CHOH}), 3.74$ $(\mathrm{s}, 1 \mathrm{H}, \mathrm{CHOH}), 3.60\left(\mathrm{ddd}, J=15.4,12.0,4.3 \mathrm{~Hz}, 2 \mathrm{H}, \mathrm{CH}_{2} \mathrm{OH}\right), 2.31-2.24(\mathrm{~m}, 2 \mathrm{H}$, $\left.\mathrm{CH}_{2} \mathrm{C}(\mathrm{O})\right), 2.04\left(\mathrm{dd}, J=14.5,7.0 \mathrm{~Hz}, 2 \mathrm{H},=\mathrm{CHCH}_{2}\right), 1.65\left(\mathrm{dt}, J=14.9,7.6 \mathrm{~Hz}, 2 \mathrm{H}, \mathrm{CH}_{2}\right.$ $\mathrm{CH}_{2} \mathrm{C}(\mathrm{O})$ ), $1.45-1.17$ (br m, 24H, $\left.\mathrm{C}_{12} \mathrm{H}_{24}\right), 0.88$ (td, $\left.J=6.8,2.6 \mathrm{~Hz}, 6 \mathrm{H}, \mathrm{CH}_{3}\right) .{ }^{13} \mathbf{C ~ N M R}$ $\left(101 \mathrm{MHz}, \mathrm{CDCl}_{3}\right) \delta 174.9(\mathrm{C}), 136.56(\mathrm{CH}), 136.3(\mathrm{CH}), 126.6(\mathrm{CH}), 116.17\left(\mathrm{CH}_{2}\right), 74.7$ $(\mathrm{CH}), 66.9\left(\mathrm{CH}_{2}\right), 66.0\left(\mathrm{CH}_{2}\right), 37.3\left(\mathrm{CH}_{2}\right), 32.5\left(\mathrm{CH}_{2}\right), 32.0\left(\mathrm{CH}_{2}\right), 31.8\left(\mathrm{CH}_{2}\right), 29.8\left(\mathrm{CH}_{2}\right)$, $29.8\left(\mathrm{CH}_{2}\right), 29.6\left(\mathrm{CH}_{2}\right), 29.5\left(\mathrm{CH}_{2}\right), 29.4\left(\mathrm{CH}_{2}\right), 29.3\left(\mathrm{CH}_{2}\right), 29.2\left(\mathrm{CH}_{2}\right), 29.1\left(\mathrm{CH}_{2}\right), 26.09$ 
$\left(\mathrm{CH}_{2}\right), 22.8\left(\mathrm{CH}_{2}\right), 22.7\left(\mathrm{CH}_{2}\right), 14.3\left(\mathrm{CH}_{3}\right), 14.2\left(\mathrm{CH}_{3}\right)$. HRMS (ESI+) calculated $\mathrm{C}_{25} \mathrm{H}_{47} \mathrm{NO}_{3}$ $[\mathrm{M}+\mathrm{H}]^{+}=410,3634$, found 410,3595 .

\section{Biology}

\section{Cell culture}

Human A549 lung adenocarcinoma cells were obtained from the American Type Culture Collection (ATCC) and grown in Ham's F-12 medium supplemented with 10\% fetal bovine serum (FBS), $1 \%$ Penicillin and Streptavidin and $2 \mathrm{mM}$ Glutamine at $37{ }^{\circ} \mathrm{C}$ in $5 \% \mathrm{CO}_{2} / 95 \%$ air.

\section{Cell viability of amide 11}

Cells were seeded in complete medium at 10.000 cells per well in 96-well plates. Twenty-four hours after seeding, media were replaced with fresh medium and compounds were added to give final concentrations of $0.02-400 \mu \mathrm{M}$. After $24 \mathrm{~h}$, the number of viable cells was quantified by the 3-(4,5-dimethylthiazol-2-yl)-2,5-diphenyltetrazolium bromide (MTT) test. Vehicle $(0.25 \%$ methanol) was used in controls. The viability for amide 11 (expressed as $\left.\mathrm{IC}_{50}\right)$ ranged between 33 to $58 \mu \mathrm{M}$.

\section{Lipid analysis}

A549 cells were seeded in $1 \mathrm{~mL}$ of medium with 10\% FBS-penicillin, streptavidin, glutamine in a 6-well plates (250.000 cells/well). Twenty-four hours later, media were replaced with fresh medium containing the compounds at the specified concentrations. After $24 \mathrm{~h}$, the medium was removed and cells were washed in PBS, collected by brief trypsinization, transferred to Eppendorf vials and resuspended in $0.1 \mathrm{~mL}$ of PBS. An aliquot $(0.01 \mathrm{~mL})$ was 
taken for cell counting. The remaining suspension was transferred to glass vials and $0.75 \mathrm{~mL}$ of chloroform/methanol (2:1) containing the internal standards (C17-sphinganine, $\mathrm{N}$ dodecanoylsphingosine, $\quad \mathrm{N}$-dodecanoylglucosylsphingosine $\quad$ and $\quad \mathrm{N}$ dodecanoylsphingosylphosphorylcholine, $0.2 \mathrm{nmol}$ each), were added. Samples were heated at $48{ }^{\circ} \mathrm{C}$ overnight and $0.075 \mathrm{~mL}$ of $1 \mathrm{M} \mathrm{KOH}$ in methanol was added, followed by $2 \mathrm{~h}$ incubation at $37{ }^{\circ} \mathrm{C}$. Finally, the mixtures were neutralized with $0.075 \mathrm{~mL}$ of $1 \mathrm{M}$ acetic acid, dried under nitrogen and the residue was dissolved in $0.150 \mathrm{~mL}$ of methanol. The liquid chromatography-mass spectrometer consisted of a Waters Aquity UPLC system connected to a Waters LCT Premier orthogonal accelerated time of flight mass spectrometer (Waters, Millford, MA), operated in positive or negative electrospray ionisation mode. Full scan spectra from 50 to $1500 \mathrm{Da}$ were acquired and individual spectra were summed to produce data points each $0.2 \mathrm{~s}$. Mass accuracy and reproducibility were maintained by using an independent reference spray via the LockSpray interference. The analytical column was a 100 $\mathrm{mm} \times 2.1 \mathrm{~mm}$ id, $1.7 \mu \mathrm{m} \mathrm{C} 8$ Acquity UPLC BEH (Waters). The two mobile phases were phase A: $\mathrm{MeOH} / \mathrm{H}_{2} \mathrm{O} / \mathrm{HCOOH}(74: 25: 1 \mathrm{v} / \mathrm{v} / \mathrm{v})$; phase $\mathrm{B}: \mathrm{MeOH} / \mathrm{HCOOH}(99 / 1 \mathrm{v} / \mathrm{v})$, both also contained $5 \mathrm{mM}$ ammonium formate. A gradient was programmed $-0.0 \mathrm{~min}, 80 \% \mathrm{~B} ; 3$ $\min , 90 \% \mathrm{~B} ; 6 \min , 90 \% \mathrm{~B} ; 15 \min , 99 \% \mathrm{~B} ; 18 \mathrm{~min}, 99 \% \mathrm{~B} ; 20 \mathrm{~min}, 80 \% \mathrm{~B}$. The flow rate was $0.3 \mathrm{~mL} \cdot \mathrm{min}^{-1}$. The column was held at $30{ }^{\circ} \mathrm{C}$. Quantification was carried out using the extracted ion chromatogram of each compound, using $50 \mathrm{mDa}$ windows. The linear dynamic range was determined by injecting standard mixtures. Positive identification of compounds was based on the accurate mass measurement with an error $<5 \mathrm{ppm}$ and its LC retention time, compared to that of standards $( \pm 2 \%)$

\section{Acknowledgments}


This work was supported by the "Fundació La Marató de TV3" (Grants 112130 and 112132), the Spanish Ministerio de Educación y Ciencia (CTQ2009-09692 and SAF2014-52223-C2-1R), the University of Barcelona (fellowship to A.R.) and by the Generalitat de Catalunya (2009SGR1037 and 2014SGR107) and "Centro de Investigación Biomédica en Red de Fisiopatología de la Obesidad y la Nutrición (CIBEROBN)", Instituto de Salud Carlos III, Madrid, Spain. We also thank Dr. Josefina Casas for helpful assistance in lipidome analysis.

\section{References}

(1) A. Boumendjel and S. P. F.Miller, Tetrahedron Lett., 1994, 35, 819-822.

(2) A. Delgado, J. Casas, A. Llebaria, J. L. Abad and G. Fabrias, Biochim. Biophys. ActaBiomembranes, 2006, 1758, 1957-1977.

(3) A. Delgado, J. Casas, A. Llebaria, J. L. Abad and G. Fabrias, ChemMedChem, 2007, 2, $580-606$.

(4) A. Boumendjel and S. P. F.Miller, US Pat., 5430 169, 1995.

(5) X. Ariza, J. Cornella, M. Font-Bardia, J. Garcia, J. Ortiz, C. Sanchez and X. Solans, Angew. Chem. Int. Ed., 2009, 48, 4202-4205.

(6) Y. Horino, M. Kimura, S. Tanaka and T. Okajima and Y. Tamaru, Chem. Eur. J., 2003, 9, 2419-2438.

(7) In our hands, the $N$-benzoyl group is still bulky enough to allow high stereoselectivities in the hydroboration step and is much easier to remove that the $N$-tosyl group (A. Rodríguez, X. Ariza, M. A. Contreras, J. Garcia, P. Lloyd-Williams, N. Mercadal and C. Sánchez, J. Org. Chem., submitted).

(8) J. M. Seco, E. Quinoa and R. Riguera, Chem. Rev. 2004, 104, 17-117.

(9) S. K. Latypov, J. M. Seco, E. Quiñoá and R. Riguera, J. Am. Chem. Soc. 1998, 120, $877-882$.

(10) A. L. Gemal and J. L. Luche, J. Am. Chem. Soc., 1981, 103, 5454-5459.

(11) J. L. Abad, I. Nieves, P. Rayo, J. Casas, G. Fabriàs and A. Delgado, J. Org. Chem., 
$2013,78,5858-5866$.

(12) D. Canals, D. Mormeneo, G. Fabriàs, A. Llebaria, J. Casas and A. Delgado, Bioorg. Med. Chem., 2009, 17, 235-241.

(13) F. Cingolani, A. H. Futerman and J. Casas, Chem. Phys. Lipids, 2016, 197, 25-32.

(14) N. M. Gardner, R. T. Riley, J. L. Showker, K. A. Voss, A. J. Sachs, J. R. Maddox and J. B. Gelineau-van Waes, Toxicol. Appl. Pharmacol., 2016, 298, 56-65.

(15) M. Castegnaro, L. Garren, D. Galendo, W. C. Gelderblom, P. Chelule, M. F. Dutton and C. P. Wild, J. Chromatogr. B. Biomed. Sci. Appl., 1998, 720, 15-24.

(16) H. C. Brown., Organic Synthesis via Boranes, John Wiley \& Sons, New York, 1975. 